
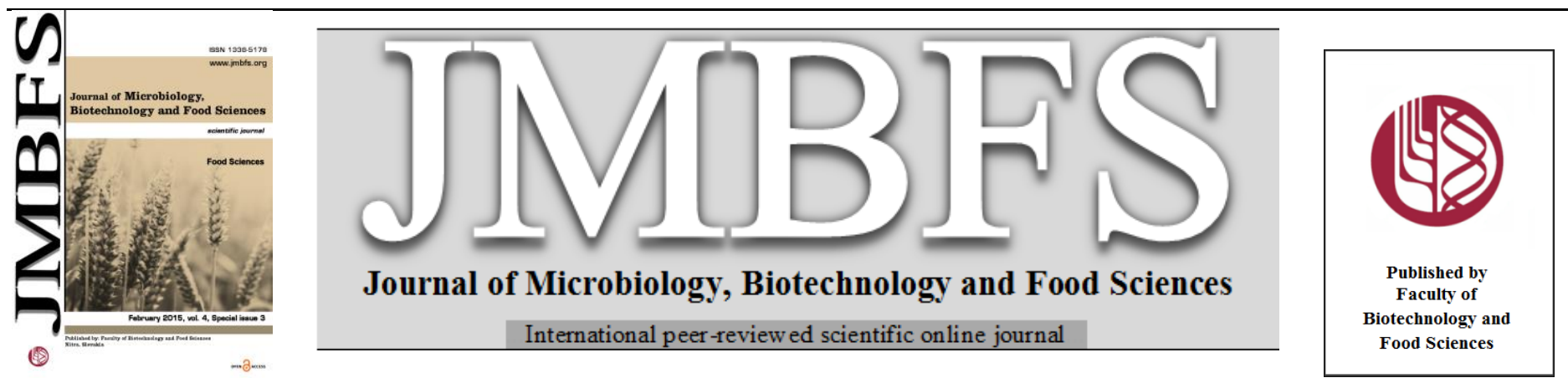

\title{
CONCENTRATION OF CADMIUM IN MEAT AND SELECTED MEATS PRODUCTS
}

\author{
Anetta Lukáčová*, Lubomír Lopašovský, Zuzana Kňažická, Jozef Golian
}

Address(es): MSc. Anetta Lukáčová

Slovak University of Agriculture, Faculty of Biotechnology and Food Sciences, Tr. A. Hlinku 2, 94976 Nitra, Slovak Republic.

*Corresponding author: anettlukacova@gmail.com

doi: 10.15414/jmbfs.2015.4.special3.102-105

\section{ARTICLE INFO}

Received 20. 11. 2014

Revised 27. 11. 2014

Accepted 28. 11. 2014

Published 2. 2. 2015

Regular article

open $\mathcal{O}$ access

\begin{abstract}
The cadmium concentrations depend on the environmental conditions and food production methods. The monitoring of cadmium concentration in meat is important for human health. The concentrations of cadmium in meat and meat products collected from central Slovakia, in the central Europe region and from different countries of West Europe were assessed using by AA spectrometer with graphite furnace (PerkinElmer AAnalyst 80, MA, USA). Within starting materials we detected the highest values of cadmium in beef from foreign production $(0.1101 \mathrm{ppm})$, followed by pork from foreign production $(0.0901 \mathrm{ppm})$ in Lovecka salama and pork thigh $(0.0523 \mathrm{ppm})$ in selected ham. In Lovecka salami we were found the highest concentration of cadmium in final samples from foreign starting materials, followed by homogenized samples from foreign starting materials, final samples from domestic starting materials and homogenized samples from domestic starting materials $(0.3728,0.3549,0.2387,0.2112 \mathrm{ppm}$, respectively). The highest concentration of cadmium in selected ham were found in final products from foreign starting materials, homogenized samples from foreign starting materials, final products from domestic starting materials and homogenized samples from domestic starting materials (0.1453, $0.1382,0.0810,0.0734 \mathrm{ppm}$, respectively). The obtained results suggested that the concentrations of cadmium are higher in homogenized samples and final products in Lovecka salami and selected ham in comparison with to starting materials. Technological process of meat processing can create a potential source of heavy metals in final products.
\end{abstract}

Keywords: Cadmium, beef, pork, pork thigh, pork bacon, meat products, atomic absorption spectrophotometry

\section{INTRODUCTION}

Meat is very rich and convenient source of nutrients, also to large extent microelements. Meat represents the main source of protein in the diet (Bendeddouche et al., 2014). The chemical composition of meat depends on both kind and degree of the feeding animal (Munoz-Olives and Camara, 2001). The need for mineral compounds depends on the age, physiological state and feed intake as well as on living conditions. Meat is a very important human food; therefore, it may potentially accumulate toxic minerals and represents one of the sources of heavy metals for humans (Baykov et al., 1996).

The main human exposure to heavy metals usually comes from food. After continuously evaluating studies on food additives and their toxicity, the WHO has come to the conclusion that even low levels of some metals, such as cadmium and lead, can give rise to diseases in humans (WHO 2000, WHO 2001). A heavy metal is defined as a metal, which is neither essential nor has beneficial effect, on the contrary, it displays severe toxicological symptoms at low levels and is defined as a metal with a specific weigh more than $5 \mathrm{~g} / \mathrm{cm}^{3}$ (Gonzales-Waller $\boldsymbol{e t}$ al, 2006). The sources of toxic metals in the environment are the fossil fuels, mining industries, waste disposals and municipal sewage. Farming and forestry also contribute to the metal content in the environment due to the uses of fertilizer, pesticide and herbicides. These metals stay permanently because they cannot be degraded in the environment. They enter into the food material and from there they ultimately make their passage into the tissue (Jayasekara $\boldsymbol{e t}$ al., 1992). Heavy metals pollutants can contaminate the products during processing (through the raw material, spices, water and packaging) by inhalation of air and penetration through the skin's surface (Raikwar et al., 2008).

Cadmium is an environmental contaminant unique among metals because of its non-biodegradable nature, long environmental persistence, diverse toxic effects, extremely protracted biological half-life, low rate of excretion from the body and predominant storage in soft tissue, although its toxic effects extend to other organs as the lungs, prostate and the bladder (Lukáč and Massányi, 2011). Cadmium has a long residence time in human tissues (10-40 years), especially in the kidneys (Rubio et al., 2006). The toxic effects of cadmium are noticeable in various ways. It can interfere with some of the organism's enzymatic reactions, substituting zinc and other metals, manifesting its action in several pathological processes such as renal dysfunctions, hypertension, arteriosclerosis, inhibition of growth, damages in the nervous system, bone demineralisation and endocrine disruption (Lafuente et al., 2004). Cadmium is suspected to be an etiological factor in various pathological processes as higher blood pressure, arteriosclerosis, growth inhibition, alterations in central nervous system, hepatic dysfunction, bronchitis and teratogenic effects (Oishi et al., 2000). Cadmium can, also, stimulate or inhibit the immune activity according to the dose. Doses of 5 and 10 $\mathrm{mg} / \mathrm{kg}$ of cadmium inhibit the humeral and cellular immune response in rats, whereas doses of 25, 50 and $100 \mathrm{mg} / \mathrm{kg}$ produce opposite effects (Massányi et al., 2007).

The aim of this study was to determine the level of cadmium in the traditional and popular meat products consumed in Slovak republic. This study is carried out to determine the levels of cadmium in Lovecka salami and selected ham products during the technological processing. The raw materials originating from domestic and foreign production were compared.

\section{MATERIAL AND METHODS}

\section{Sample collection}

To reach representative samples, average composition and characteristics of the goods were analysed. The concentration of cadmium was determined in total 160 samples during the year 2013 from raw materials and final product, respectively. Raw materials from domestic production were collected in central Slovakia, in the central Europe region. Raw material from foreign was collected from different countries of West Europe. The collection of samples during the manufacturing process was carried out under the following scheme:

"Lovecka salami" - basic raw material (beef, pork and pork bacon) was collected; than samples of homogenized meat with additives (salt, sodium ascorbate, erythorbic acid, ground black pepper, sugar, garlic, starter culture) and finally the actual sample of the final product after heat treatment, cooling to $25^{\circ} \mathrm{C}$ and drying in climates with aw $=0.95$ was analyze.

„Selected ham“ was collected basic raw (pork thigh), than samples of homogenized meat with additives (salt, Sodium Nitrite, sodium pyrophosphate, sodium tripolyphosphate, Ascorbic acid) and finish product after heat treatment. 


\section{Sample preparation}

Collected samples were placed to plastic bags, and frozen $\left(-18^{\circ} \mathrm{C}\right) \cdot 30-50 \mathrm{mg}$ of meat or homogenized meat samples and final products were used in the protocol The samples were dried at $105^{\circ} \mathrm{C}$ in order to obtain dry mass of meat samples. All the samples were mineralized in the hot nitric acid (HNO3 65\% Ultranal ${ }$, $\mathrm{POCH}$, Poland) at the temperature of $90^{\circ} \mathrm{C}$ until complete disso-lution of tissues using VELP Scientifica DK 20 (VELP Scientifica, Italy) mineralizator. Later the samples were thinned with spectrally pure water to cubic capacity of $10 \mathrm{ml}$. The mineralized samples were analyzed by the AA spectrometer with the graphite furnace (PerkinElmer AAnalyst 800; MA, USA) to determine cadmium of concentration (Binkowski, et. al., 2013). Final results were given in ppm (mg.kg ${ }^{1}$ ) for meat and other samples.

\section{RESULTS AND DISCUSSION}

In this study we determined the content of cadmium in Selected ham samples in pork thigh, homogenized samples with additives additives (salt, Sodium Nitrite, sodium pyrophosphate, sodium tripolyphosphate, Ascorbic acid) and finish product after heat treatment and Lovecka salami specifically in: beef, pork, pork bacon, homogenized samples with additives (salt, sodium ascorbate, erythorbic acid, ground black pepper, sugar, garlic, starter culture and final samples) was determined. Also the raw materials originating from domestic and foreign production were compared. The concentration of cadmium in the studied in Lovecka salami are given in table 1 . The level of cadmium in beef from domestic production $(0.0321 \pm 0.0106 \mathrm{ppm})$ was lower than in beef from foreign production $(0.1101 \pm 0.0313 \mathrm{ppm})$. Cd content in the beef samples from foreign production was significantly higher $(\mathrm{P}<0.05)$ compared to those from domestic production. The obtained results are in agreement with the obtained by Koréneková $\boldsymbol{e t}$ al. (2002), their results ranged from 0.070 to $0.387 \mathrm{ppm}$ in biological samples of cattle from three regions (Haniska, Cestice and Perín) in Slovakia. The average values for cadmium in our study were higher than the corresponding values for cadmium in meat from cattle produced in Algeria $(0.0076 \pm 0.03 \mathrm{ppm})$ (Bendeddouche et al. 2014) who they further state that Cd concentrations in meat depend on the concentration of $\mathrm{Cd}$ in the animal feed. The hazardous effect was more visible at higher bioaccumulation of heavy metals during vegetative growth stage. However higher average concentration of $\mathrm{Cd}$ were observed in in beef products in Saudi Kingdom during $2011-2012(3.06 \pm 0.16 \mathrm{ppm})$ and residue levels in the liver $(0.0097 \mathrm{ppm})$ and muscle $(0.001 \mathrm{ppm})$ of cattle from Galicia (Spain) (Alturiqi et al. 2012, Lopez-Alonso et al., 2000) in comparison to our results. The level of cadmium in pork from foreign production was higher $(0.0901 \pm 0.0178 \mathrm{ppm})$ than in pork from domestic production $(0.0435 \pm 0.0142$ $\mathrm{ppm})$. Cadmium data showed noticeable insignificant difference between $\mathrm{Cd}$ content in pork from domestic production and pork from foreign production. Gonzales -Waller $\boldsymbol{e t}$ al. (2006) reported that average amount of cadmium in pork and pork meat products in Tenerife Island, Spain ranged between 0.00549 ppm for pork and 0.00650 ppm for pork meat products. Iwegbue et al. (2008) reported mean levels of $\mathrm{Cd}$ in Turkey meat collected from Ughelli zone in Southern Nigeria $1.29 \pm 0.22 \mathrm{ppm}$. Cadmium concentrations in meat increase with the age of the animal and depend on the concentrations of $\mathrm{Cd}$ in the feed (Hecht, 1983). Vos et al. (1987) stated that cadmium may accumulate in the human body and may induce kidney dysfunction, skeletal damage and reproductive deficiencies. Mean contents of cadmium in pork bacon from foreign production $(0.0379 \pm 0.0174 \mathrm{ppm})$ was higher than in pork bacon from domestic production $(0.0189 \pm 0.0101 \mathrm{ppm})$. Cadmium data showed noticeable insignificant difference between $\mathrm{Cd}$ content in pork bacon from domestic production and pork bacon from foreign production. The highest level of cadmium in bacon was observed in pork products in Chennai (India) (Santhi et al., 2008) in mean $0.220 \pm 0.031 \mathrm{ppm}$. Their results indicated that contamination of meat products with cadmium might occur in three ways, on from animal grazing on lands spread with sewage sludge or phosphate fertilizers and another from animal grazing on lands contaminated with industrial cadmium effluent. Secondary cadmium contamination of food occurs as a result of its use in food processing (Zurera-Cosano, 1993). Muller $\boldsymbol{e t}$ al. (1996) that reported that sausages had higher cadmium content than the raw meat. The addition of spices during production of homogenized samples might be the main reason since spices could contain cadmium concentrations up to $200 \mathrm{mg} / \mathrm{g}$ (Santhi et al., 2008). The data is consistent with our following results.

Table 1 Basic variation statistical characteristics of cadmium concentration in the raw materials and final product "Lovecka" salami

\begin{tabular}{|c|c|c|c|c|c|c|c|c|c|c|}
\hline \multirow[b]{2}{*}{ Cd } & \multicolumn{2}{|c|}{ beef } & \multicolumn{2}{|c|}{ pork } & \multicolumn{2}{|c|}{ pork bacon } & \multicolumn{2}{|c|}{ homogenized samples } & \multicolumn{2}{|c|}{ final sample } \\
\hline & $\mathrm{D}$ & $\mathrm{F}$ & $\mathrm{D}$ & $\mathrm{F}$ & $\mathrm{D}$ & $\mathrm{F}$ & $\mathrm{D}$ & $\mathrm{F}$ & $\mathrm{D}$ & $\mathrm{F}$ \\
\hline$\overline{\mathrm{X}}$ & 0.0321 & 0.1101 & 0.0435 & 0.0901 & 0.0189 & 0.0379 & 0.2112 & 0.3549 & 0.2387 & 0.3728 \\
\hline Min & 0.0213 & 0.0657 & 0.0243 & 0.0567 & 0.0013 & 0.0124 & 0.1253 & 0.2100 & 0.1587 & 0.2400 \\
\hline Med & 0.0307 & 0.1056 & 0.0439 & 0.0915 & 0.0186 & 0.0351 & 0.2166 & 0.3600 & 0.2457 & 0.3349 \\
\hline Max & 0.0487 & 0.1647 & 0.0653 & 0.1253 & 0.0324 & 0.0653 & 0.2984 & 0.4900 & 0.3583 & 0.5400 \\
\hline SD & 0.0106 & 0.0313 & 0.0142 & 0.0178 & 0.0101 & 0.0174 & 0.0486 & 0.1007 & 0.0574 & 0.1127 \\
\hline SEM & 0.0033 & 0.0099 & 0.0045 & 0.0056 & 0.0032 & 0.0055 & 0.0154 & 0.0319 & 0.0182 & 0.0357 \\
\hline CV & 32.25 & 28.00 & 32.60 & 19.69 & 51.80 & 45.68 & 22.75 & 28.40 & 24.04 & 30.25 \\
\hline $\mathbf{P}$ & \multicolumn{2}{|c|}{$0.0204(\mathrm{P}<0.05)$} & \multicolumn{2}{|c|}{0.4739 (NS) } & \multicolumn{2}{|c|}{ (NS) } & \multicolumn{2}{|c|}{$\mathrm{P}<0.001$} & \multicolumn{2}{|c|}{$\mathrm{P}<0.001$} \\
\hline
\end{tabular}

Legend: $\bar{X}$ - mean, SD - standard deviation, Med (x). - Median, CV (\%) - coefficient of variation, D - domestic and F - foreign production, NS - non significant, Cd - cadmium

The average concentration of cadmium was higher in homogenized samples with additives and spices in comparison the starting materials. The level of cadmium in the homogenized samples from foreign starting materials was $0.3549 \pm 0.1007$ ppm. The average cadmium concentration was $0.2112 \pm 0.0486 \mathrm{ppm}$ in homogenized samples from domestic starting materials. The mean level of cadmium in the homogenized samples from foreign production was higher $(\mathrm{P}<0.001)$ than in homogenized samples from domestic production. In final product Lovecka salami from domestic production $(0.2387 \pm 0.0574 \mathrm{ppm})$ was lower than in final product Lovecka salami from foreign production $(0.3728 \pm 0.1127 \mathrm{ppm}) . \mathrm{Cd}$ content in the final sample from foreign production was significantly higher $(\mathrm{P}<0.001)$ compared to those from final product from domestic production. Santhi et al. (2008) in their study reported that sausages and salami had the highest concentration of cadmium among the products analysed could be due to the processes involved during canning. The biological half-life of cadmium in the human kidney is long and has been estimated to be 10 to 30 years (Nordberg, 1999). The levels of cadmium in pork and beef meat from foreign production, homogenized samples and final product are above guideline of $0.050 \mathrm{mg} / \mathrm{kg}$ (Commission regulation 488/2014 2014).

The concentrations of cadmium in the selected ham are presented in Table 2 . The mean $\mathrm{Cd}$ concentrations in pork thigh ranged between 0.0179 to $0.0782 \mathrm{ppm}$. The concentration of cadmium in pork thigh from foreign production $(0.0523 \pm 0.0151$ $\mathrm{ppm})$ was higher than in pork thigh from domestic production $(0.0204 \pm 0.0028$ ppm). Data showed noticeable insignificant difference between $\mathrm{Cd}$ content in pork thigh from domestic production and pork thigh from foreign production. The cadmium concentrations obtained from this study were lower than those recorded Demirezen-Uruc (2006). Their levels of cadmium in pork samples collected in Kayseri (Turkey) ranged from 0.77 to $1.04 \mathrm{ppm}$. The mean level of $\mathrm{Cd}$ in the homogenized samples from foreign production was higher $(0.1303 \pm 0.0460 \mathrm{ppm})$ than concentration of cadmium detected in the homogenized samples from domestic production $(0.0705 \pm 0.0201 \mathrm{ppm})$. 
Table 2 Basic variation statistical characteristics of lead concentration in the raw materials and final product „Selected ham“

\begin{tabular}{|c|c|c|c|c|c|c|c|c|}
\hline \multirow[t]{2}{*}{ Cd } & \multicolumn{2}{|c|}{ pork thigh } & \multicolumn{2}{|c|}{ homogenized samples } & \multicolumn{2}{|c|}{$\begin{array}{c}\text { smoked } \\
\text { homogenized samples } \\
\end{array}$} & \multicolumn{2}{|c|}{ final sample } \\
\hline & $\mathrm{D}$ & $\mathrm{F}$ & $\mathrm{D}$ & $\mathrm{F}$ & D & $\mathrm{F}$ & $\mathrm{D}$ & $\mathrm{F}$ \\
\hline$\overline{\mathrm{X}}$ & 0.0204 & 0.0523 & 0.0705 & 0.1303 & 0.0734 & 0.1382 & 0.0810 & 0.1453 \\
\hline Min & 0.0179 & 0.0345 & 0.0356 & 0.0654 & 0.0422 & 0.0953 & 0.0382 & 0.0654 \\
\hline Med & 0.0197 & 0.0564 & 0.0752 & 0.1307 & 0.0782 & 0.1354 & 0.0812 & 0.1516 \\
\hline $\operatorname{Max}$ & 0.0254 & 0.0782 & 0.0952 & 0.1987 & 0.0952 & 0.1984 & 0.1254 & 0.1987 \\
\hline SD & 0.0028 & 0.0151 & 0.0201 & 0.0460 & 0.0184 & 0.0355 & 0.0238 & 0.0451 \\
\hline SEM & 0.0009 & 0.0048 & 0.0064 & 0.0146 & 0.0059 & 0.0113 & 0.0076 & 0.0143 \\
\hline CV & 14.04 & 29.15 & 28.61 & 35.31 & 25.20 & 25.73 & 29.50 & 31.12 \\
\hline $\mathbf{P}$ & \multicolumn{2}{|c|}{$0.0752(\mathrm{NS})$} & \multicolumn{2}{|c|}{$\mathrm{P}<0.001$} & \multicolumn{2}{|c|}{$\mathrm{P}<0.001$} & \multicolumn{2}{|c|}{$\mathrm{P}<0.001$} \\
\hline
\end{tabular}

Legend: $\quad \bar{X}$ - mean, SD - standard deviation, Med (x). - Median, CV (\%) - coefficient of variation, D - domestic and F - foreign production, NS - non significant, Cd - cadmium

In final product selected ham from foreign production higher concentration of cadmium $(0.1453 \pm 0.0451 \mathrm{ppm})$ than in final product Selected ham from domestic production $(0.0810 \pm 0.0238 \mathrm{ppm})$ were found. Our results were lower than obtained by Alturiqi - Albedair (2012). They have shown mean concentration of cadmium in sausage is $3.33 \pm 0.17 \mathrm{ppm}$. Santhi $\boldsymbol{e t}$ al. (2008) stated that average amount of this metal in salami was $0.296 \pm 0.036 \mathrm{ppm}$.

However, the obtained result of cadmium in the samples with the exception of samples pork thigh from domestic production exceeds the permissible levels $0.050 \mathrm{mg} / \mathrm{kg}$ (Commission regulation 488/2014 2014).

\section{CONCLUSION}

The levels of cadmium in meat and meat products consumed by the population in Slovakia were determined. The cadmium levels in pork and beef meat from foreign production, homogenized samples, final product in Lovecka salami and pork thigh from foreign production, homogenized samples and final products in Selected ham analysed in this study were exceeds the permissible levels. The cadmium levels in beef, pork from domestic production and pork bacon from domestic and foreign production in Lovecka salami and pork thigh in Selected ham from domestic production were below the legal limits by the current EU legislation. The obtained results suggested that the concentrations of cadmium are higher in homogenized samples and final products in Lovecka salami and selected ham in compared starting materials. Technological treatments are important for levels of trace elements in meat products. Improvements in the food production and processing technology are food contamination with various environmental pollutants and heavy metals.

Acknowledgments: This work was financially supported by the European Community under project No. 26220220180: Building Research Centre „AgroBioTech" and VEGA project No. 1/0857/14 from the Slovak ministry of Education.

\section{REFERENCES}

ALTURIQI, S.A., ALBEDAIR, A. L. 2012. Evaluation of some heavy metals in certain fish, meat and meat products in Saudi Arabian markets. Egyptian Journal of Aquatic Research 38, 45-49.

https://dx.doi.org/10.1016/j.ejar.2012.08.003

BAYKOV, B.D., STOYANOV, M.P., GUGOVA, M.L. 1996. Cadmium and lead bioaccumulation in male chickens for high food concentrations. Toxicological and Environmental Chemistry, vol.54, no. 2, p. 155-159.

BENDEDDOUCHE B., ZELLAGUE R., BENDEDDOUCHE E., 2014. Levels of selected heavy Metals in Fresh Meat from Cattle, Sheep, Chicken and Camel Produced in Algeria, Annual Research \& Review in Biology, 4(8): 1260-1267. BINKOWSKI, L.J., STAWARZ, M.R., ZAKRZEWSKI, M. 2013. Concentrations of cadmium, copper and zinc in tissues of Mallard and Coot from southern Poland. Journal of Environmental Science and Health. 5, 410-415 https://dx.doi.org/10.1080/03601234.2013.742725

COMMISSION REGULATION (EU) No. 488/2014 amending Regulation (EC) No. 1881/2006 as regards maximum levels of cadmium in foodstuffs.

DEMIREZEN, D., URUC, A., 2006. Comparative study of trace elements in certain fish, meat and meat products. Meat Science, vol. 74, no. 1, p. 255-260. https://dx.doi.org/10.1016/j.meatsci.2006.03.012

GONZALES-WALLER, D., KARLSSON L., CABALLERO, A., HERNANDEZ, F., GUTIERREZ, A., GONZALEZ-IGALESIAS, T., MARINO, M., HARDISSION A., 2006. Lead and cadmium in meat and meat products consumed by the population in Tenerife Islands. Food Additives and Contaminants, vol. 23, no. 3, p. 757-763.

https://dx.doi.org/10.1080/02652030600758142

HECHT, H., 1983. Toxische Sewermetalle in Fleish und Innerein verschiedener Tierarten. Fleischwitschaft 63, 544-558.

IWEGBUE, C.M.A., NWAJEI G. E., IYOHA, E.H. 2008. Heavy metal residues of chicken meat and Gizzard and Turkey meat consumed in Southern Nigeria. Bulgarian Journal of Veterinary Medicine, No 4, 275- 280.

JAYASEKARA, S.U., SAMARAJEEWA, U., JAYAKODY, A.N. 1992. Trace metals in foods of animal origin in Srilanka. ASEAN Food Journal, vol. 7, no. 2, p. 105-107.

KORENEKOVA, B.; SKALICKA, M.; NAD', P. 2002. Concentration of some heavy metals in cattle reared in the vicinity of a metallurgic industry. Veterinarski Arhiv., 72, (5) 259-267.

LAFUENTE, A., GONZÁLEZ-CARRACEDO, A., ESQUIFINO, A: 2004 Differential effects of cadmium on blood lymphocyte subsets. Biometals, 17:451456

https://dx.doi.org/10.1023/B:BIOM.0000029441.20037.72

LÓPEZ-ALONSO, M., BENEDITO, J.L., MIRANDA, M., CASTILlo, J., HERNANDEZ, J., SHORE, R.F. 2000. Toxic and trace elements in liver, kidney and meat from cattle slaughtered in Galicia (Spain). Food Additives \& Contaminants, 17, 447-457.

https://dx.doi.org/10.1080/02652030050034028

LUKÁČ, N. - MASSÁNYI, P., 2011. Risk Factors and Biological Systems, Slovak University of Agriculture in Nitra, volume I., ISBN 978-80-552-0567-0.

MASSÁNYI, P., LUKÁČ, N., SLIVKOVÁ, J., KOVÁČIK, J., MAKAREVICH, A,V., CHRENEK, P., TOMAN, R., FORGÁCS, Z., SOMOSY, Z., STAWARZ, R., FORMICKI, G. 2007. Mercury-induced alterations in rat kidneys and testes in vivo. Journal of Environmental Science and Health, A42, 865-870.

https://dx.doi.org/10.1080/10934520701370410

MULLER, M., ANKE, M., HARTMANN, E., GUNTHER, H.I. 1996. Oral cadmium exposure of adults in Germany 1: Cadmium content of foodstuffs and beverages. Food Additives \& Contaminants, 13: 359-378.

MUNOZ-OLIVES, R., CAMAR C., 2001. Speciation related to human health. In: Trace element speciation for environment food and health. The Royal Society of Chemistry, pp 331-353.

NORDBERG, G., 1999. Excursions of intake above ADI: Case study on cadmium. Regulatory Toxicology Pharmacology, 30:57 - 62 .

OISHI, S., NAKAWA, J., ANDO, M. 2000. Effect of cadmium administration on the endogenous metal balance in rats. Biological Trace Elements Research, 31, 257-278.

https://dx.doi.org/10.1385/BTER:76:3:256

RUBIO, C., GONZÁLEZ-IGLESIAS, T., REVERT, C., REGUERA, J.I., GUTIÉRREZ, A.J., HARDISSON, A. 2005. Lead dietary intake in a Spanish Population (Canary Islands). Journal of Agricultural and Food Chemistry, vol. 53 , no. 2, p. 6543-6549.

https://dx.doi.org/10.1021/jf058027v

RAIKWAR, M., KUMAR, P. SINGH, M., SINGH, A. 2008. Toxic effect of heavy metals in livestock health. Veterinary World, 1(1): 28-30.

SANTHI, D., BALAKRISHNEN, V., KALAIKANNAN, A., RADHAKRISHNAN, K.T. 2008. Presence of heavy metals in pork products in Chennai. American Journal of Food Technology, vol. 3, no. 3, p. 192-199.

VOS, G., HOVENS, J.P.C., DELFT, W.V., 1987. Arsenic, cadmium, leads and mercury in meat, livers and kidneys of cattle slaughtered in The Netherlands during 1980-1985. Food Additives and Contaminants, 4, 73- 88. 
WORLD HEALTH ORGANISATION (WHO). 2000. Lead. In: Safety evaluation of certain food additives and contaminants. Fifty-third meeting of the Joint FAO/WHO Expert Committee on Food Additives (JECFA). Geneva: WHO Food Additives Series 44. p. 273-312.

WORLD HEALTH ORGANISATION (WHO). 2001. Cadmium. In: Safety evaluation of certain food additives and contaminants. Fifty-fifth meeting of the Joint FAO/WHO Expert Committee on Food Additives (JECFA). Geneva: WHO Food Additives Series 46. p. 247-305.

ZURERA-COSANO, G., 1993. Cadmium. In: Encyclopaedia of Food Science, Food Technology and Nutrition. Academic press, London. 